УДК [326+930+94] (477-924.86) «652»

DOI: https://doi.org/10.33782/eminak2019.1(25).212

\title{
РАБОВЛАСНИЦТВО В ОЛЬВІЙСЬКОМУ ПОЛІСІ У V-III СТ. ДО Н.Е.: ІСТОРІОГРАФІЯ, ДЖЕРЕЛА, ПЕРСПЕКТИВИ ДОСЛІДЖЕНЬ
}

\author{
Олександр Одрін \\ Інститут історії України НАН України (Київ, Україна) \\ e-mail: olodrin@ukr.net \\ ORCID: https://orcid.org/0000-0002-2729-6548
}

Стаття присвячена аналізу джерельної бази й історіографії історії рабовласницьких відносин в Ольвії Понтійській. Дослідження рабовласництва в Ольвійському полісі довго гальмувалися через обмеженість джерельної бази. В останні десятиліття до наукового обігу було введено нові джерела, інформація яких дає змогу суттєво інтенсифікувати вивчення соціальної історії Ольвії, зокрема і рабовласницьких відносин. У статті аналізуються дані епіграфічних і писемних джерел та окреслюються напрямки подальших досліджень, які мають базуватися на комплексному вивченні епіграфічних та археологічних джерел із врахуванням теоретичних напрацювань сучасної історіографії.

Ключові слова: Ольвія, рабовласництво, работоргівля, історіографія, Північне Причорномор'я

Вже скоро як два століття 1 однією з фундаментальних проблем антикознавства $€$ оцінка ролі рабовласницьких відносин у соціальному, економічному та й культурному житті античного суспільства. Починаючи від класичної праці А. Валлона², постійно виходять нові й нові монографії з «рабської» проблематики, не говорячи про окремі статті, число яких вимірюється тисячами. В Європі останнє десятиліття активно діють три дослідницькі центри вивчення античного рабовласництва: у Майнці, Безансоні та Ноттінгемі ${ }^{3}$. Тим не менш, і до сьогодні науковці не дійшли, наприклад, спільного знаменника в оцінці ролі рабської праці в античному господарстві, висловлюючи часом діаметрально протилежні думки - від твердження про її всюдисущість і до заперечення скільки-небудь важливої ролі невільників у більшості галузей економіки, окрім хіба кількох, таких як гірнича справа та, меншою мірою, окремі ремісничі виробництва 4 .

Безумовно, при таких об’ємах історіографічних напрацювань і при такій поляризації думок, будь-який, навіть вибірковий огляд основних концепцій повинен мати монографічний характер. Тож у цій статті варто обмежитись розглядом лише тих кількох важливих ідей, які, безпосередньо, чи опосередковано, вплинули на вивчення історії рабовласництва в античних державах північного узбережжя Понту зага-

\footnotetext{
1 Якщо рахувати від дати виходу першого видання праці Анрі Валлона у 1847 році. Хоча Валлон аж ніяк не був першим, хто взагалі торкнувся питань рабовласництва в античному світі (див.: Ленцман Я.А. Рабство в микенской и гомеровской Греции. Москва, 1963. С. 14-16), але саме ця фундаментальна праця стала наріжним каменем подальших досліджень античного рабовласництва.

2 Wallon H. Histoire de l'esclavage dans l'Antiquité. Paris, 1847.

3 Див: Lewis D. Greek Slave Systems in their Eastern Mediterranean Context. c. 800-146 BC. Oxford, 2018.

4 Звичайно, тут ідеться лише про покупних рабів, а не про ілотів та їм подібних.
} 
лом, і в Ольвії зокрема, зосередивши основну увагу на «локальній», північнопонтійській, історіографії.

Певно, однією з ключових ланок у формуванні сучасних уявлень про роль рабства у Давній Греції були праці Мозеса Фінлі (серія статей, згодом опублікована у вигляді монографії «Давнє рабство і сучасна ідеологія»5), в якій він сформулював ідею античного суспільства як «рабського суспільства» (slave society), яке цим самим протиставлялося давньосхідним «суспільствам з рабами» (society with slaves)6. Таким чином, Фінлі наголошував на фундаментальній ролі рабовласницьких відносин саме в античному суспільстві. Ця ідея авторитетного дослідника, на відміну від багатьох інших, донедавна практично не піддавалася критиці (лише нещодавно Д. Льюіс поставив під сумнів принципову відмінність між античним і східним рабовласництвом$\left.^{7}\right)$, заклавши концептуальну базу для подальших досліджень античного рабства. Щоправда під «рабським» (чи рабовласницьким) суспільством дослідники часто розуміли переважно лише такі великі й економічно розвинені поліси, як Афіни, благо джерельна база, яка час від часу поповнювалась новими епіграфічними знахідкамия, дозволяла базувати дослідження на конкретному джерельному матеріалі, а не лише на загальних міркуваннях.

Зовсім по-іншому, зважаючи на обмеженість джерельної бази, довгий час складалася ситуація з дослідженням рабовласництва на віддаленій периферії античного світу, та ще й у відносно невеликих полісах, таких як більшість полісів Північного Причорномор'я. Тут довгий час «джерельний голод» не лише гальмував проведення відповідних досліджень, але й дозволяв взагалі ставити під сумнів скільки-небудь значне поширення рабовласницьких відносин. Яскравим прикладом такого підходу $\epsilon$ вивчення історії рабовласництва в Ольвійському полісі - чи не єдиній з античних держав Північного Причорномор'я, де існування рабів було однозначно засвідчене не лише епіграфічними чи археологічними, а й писемними джерелами.

Втім, доволі довго кількість цих джерел була, м’яко кажучи, вкрай незначною, якщо не сказати мікроскопічною. Головним джерелом, яке засвідчувало існування рабів в Ольвії, були відомості Макробія (Sat. I. 11.33) про звільнення рабів борисфенітами під час походу Зопіріона, що було одним із дієвих заходів утриматись під час небезпеки. I хоча ця обставина могла б наштовхнути на думку про існування доволі значної кількості рабів (інакше їх звільнення не мало б помітного ефекту), очевидно, більшості дослідників цей одиничний факт, не підкріплений іншими даними, не видавався достатньо вагомим.

Не надто багато до цього додавали відомості Діогена Лаертського (IV, 46), що філософ-кінік Біон Борисфеніт був сином вільновідпущеника, хіба що свідчили про існування поширеної в античному світі практики манумісій у IV ст. до н.е. і в Ольвії (зважаючи на загальноприйняту дату народження Біона - 325 р. до н.е.).

Нарешті, третім джерелом про існування рабовласництва в Ольвії, цього разу не

\footnotetext{
${ }^{5}$ Finley M. Ancient Slavery and Modern Ideology. New York, 1980.

6 Див. детальніше про ідеї Фінлі стосовно рабовласництва та їх вплив на антикознавство: Vlassopoulos K. Finley's Slavery // M.I. Finley: An Ancient Historian and his Impact. Cambridge, 2016. P. 7699.

7 Lewis D. Greek Slave Systems in their Eastern Mediterranean Context...

8 Про роль епіграфічних джерел у вивченні античного рабства, див.: Chaniotis A. Epigraphic Evidence // The Oxford Handbook of Greek and Roman Slaveries. URL: http://www.oxfordhandbooks.com/view/10.1093/oxfordhb/9780199575251.001.0001/oxfordhb9780199575251-e-3
} 
писемним, а епіграфічним, був, звичайно, декрет на честь Протогена [IOSPE I², 32] ${ }^{9}$, в якому згадувались ойкети - термін, який найчастіше використовувався для позначення домашніх та/або сільськогосподарських рабів ${ }^{10}$. Втім, саме полісемантичність цього терміну дозволяла трактувати текст Декрету по-різному11 - його можна було вважати і свідченням наявності в Ольвії рабів, зайнятих у сільськогосподарському виробництві, і свідченням наявності рабів загалом, і навіть ставити під сумнів, що у тексті йшлося саме про рабів, а не про інші категорії залежного населення.

Слід наголосити, що всі ці відомості відносились до доволі пізніх періодів існування Ольвійського полісу - пізньокласичного й елліністичного, що лишало простір для довільних спекуляцій про поширення (чи непоширення) рабовласницьких відносин на початкових етапах історії Ольвії.

Не можна сказати, що, попри всі ці складнощі, проблема не привертала до себе увагу дослідників, тим більше, що в офіційній радянській версії марксизму (особливо у 30-50-ті роки минулого століття) всіляко педалювалася тема класового протистояння в античному суспільстві між рабами та рабовласниками. Причому іноді, коли фактів такої боротьби бракувало, дослідникам доводилось «підганяти» факти під схему, яскравим прикладом чого $є$ відверто ідеологізована в офіційно-марксистському дусі концепція «рабського повстання Савмака» авторства С.О. Жебельова ${ }^{12}$.

Яскравим прикладом умоглядних побудов можуть слугувати праці авторитетного радянського антикознавця В.Д. Блаватського ${ }^{13}$, який базував свої висновки то на пасажі Демосфена про відправку продуктів сільськогосподарським робітникам (adv. Lacr., 32), який не піддається однозначному трактуванню (чи були ці робітники вільнонайманими чи рабами), то на згаданій вище «теорії» Жебельова. I вже зовсім анекдотично виглядає зараз, після масштабних розкопок сільської округи Ольвії, твердження Блаватського про те, що ольвіополіти майже не використовували працю сільськогосподарських рабів через «незначну» площу полісної хори ${ }^{14}$, хоча цей висновок і базувався на тогочасних уявленнях про належність поселень в околицях міста варварському населенню.

\footnotetext{
9 Корпус стародавніх написей Північного Причерноморья (Inscriptiones antiquae Orae Septentrionalis Ponti Euxini graecae et latinae - IOSPE). Друге видання.

10 Стислий огляд античної термінології для позначення різних категорій рабів (з літературою) див. у свіжій праці М. Зельник-Абрамовіц (Zelnick-Abramovitz R. Greek and Roman Terminologies of Slavery // The Oxford Handbook of Greek and Roman Slaveries. URL: http://www.oxfordhandbooks.com/view/10.1093/oxfordhb/9780199575251.001.0001/oxfordhb9780199575251-е-41). На матеріалах 3 Надчорномор'я див. у статті Н.В.Завойкіної та Н.А. Павличенко: (Завойкина Н.В., Павличенко Н.А. Письмо на свинцовой пластине Патрея // Фанагория. Т. 4. Результаты археологических исследований. Москва, 2016. С. 235-242).

11 Див.: Марченко К.К. Греки и варвары Северо-Западного Причерноморья скифской эпохи // Греки и варвары Северного Причерноморья в скифскую эпоху. Санкт-Петербург, 2005. С. 129-136. 12 Жебелев С.А. Последний Перисад и скифское восстание на Боспоре // Вестник древней истории. 1938. № 3. С. 43-71 (перша редакція була опублікована ще у 1933 році).

Про роль ідеології у радянських дослідженнях античних держав Північного Причорномор'я, а також - у питаннях рабовласництва, див. праці українського еміграційного дослідника Сергія Коцевалова (Коцевалов А.С. Античная история и культура Северного Причерноморья в советском научном исследовании. Мюнхен, 1955; Его же. Античное рабство и революции рабов в советской исторической литературе. Мюнхен, 1956).

13 Блаватский В.Д. Земледелие в античных государствах Северного Причерноморья. Москва, 1953; Его же. Рабство и его источники в античных государствах Северного Причерноморья // Советская археология. 1954. ХХ. С. 31-56.

14 Блаватский В.Д. Земледелие в античных государствах Северного Причерноморья... С. 195.
} 
Така надмірна спекулятивність побудов з часом (особливо, коли послабшав ідеологічний тиск) закономірно викликала іншу крайність - надмірну обережність. Так, що інший авторитетний радянський фахівець Д.П.Каллістов у статті, спеціально присвяченій рабству в давньому Причорномор'ї, розглядає по суті лише рабовласницькі відносини у кочовиків і приходить до цілком слушного висновку, що рабство у скіфів було зовсім нерозвинутим, порівняно з античним, на чому успішно й зупиняється, по суті уникнувши будь-яких, навіть найобережніших, оціночних суджень відносно поширення рабовласницьких відносин в античних державах Північного Причорномор'я 15.

3 того часу «рабська» тематика, попри офіційну марксистську настанову, яка мала б концентрувати увагу дослідників на соціально-економічній проблематиці, загалом зникає зі сторінок праць, присвячених історії античних держав Північного Причорномор'я, й Ольвії зокрема. Зрозуміло, що змінити ситуацію могла лише поява нових джерел, але вони почали вводитись до наукового обігу лише на початку 1970-х років 16 .

У 1971 р. Ю.Г. Виноградовим було опубліковано знайдений на Березані великий лист на свинцевій пластинці, датований другою половиною VI ст. до н.е. ${ }^{17}$ Саме початком 70-х років минулого століття можна датувати новий період дослідження історії рабовласництва в Ольвії Понтійській, адже цей лист - лист Ахіллодора - містив надзвичайно цікаві відомості про соціально-економічний устрій пізньоархаїчної Ольвії. Читання окремих пасажів викликало суттєві розбіжності між епіграфістами 18 , більшість яких не погоджувалась із низкою інтерпретацій Ю.Г. Виноградова19, але принаймні декілька принципових положень були загальноприйнятими.

По-перше, це стосувалося висловлювання такого собі Матасія, що Анаксагор, господар автора листа (чи то власник, чи то наймач) нині володіє його, Матасія, майном - будівлями, рабами та рабинями. Відповідно, перед нами поставало одразу двоє рабовласників - Анаксагор і Матасій, які володіли кільканадцятьма рабами.

По-друге, спроба захоплення автора листа у рабство ілюструвала практику силового поневолення у пізньоархаїчній Ольвії ${ }^{0}$. На думку Дж-П. Вільсона, це могло свідчити про те, що Ахіллодор був вільновідпущеником²1. А якщо зауважити, що Ахіллодор, скоріше за все, був перевізником торгівельного вантажу, то можна зробити логічний висновок, що в архаїчній Ольвії раби або вільновідпущеники були задіяні у

\footnotetext{
15 Каллистов Д.П. Рабство в Северном Причерноморье V-III вв. до н.э. // Рабство на периферии античного мира. Ленинград, 1968. С. 193-221.

16 Епіграфічні пам'ятки, які б містили інформацію про рабовласництво в Ольвії, знаходились і раніше, але в силу різних причин не вводились до наукового обігу. Так, ще у 1968 р. було знайдено «Лист жерця», але опубліковано його було лише майже два з половиною десятиліття по тому (див. нижче).

17 Виноградов Ю.Г. Древнейшее греческое письмо с острова Березань // Вестник древней истории. 1971. № 4. С. 74-100.

18 Огляд літератури і різночитань див у: Ceccarelli P. Ancient Greek Letter Writing: A Cultural History (600 BC - 150 BC). Oxford, 2013. P. 335.

19 Зокрема, із розумінням терміну «фортегесій» як людини рабського статусу, перевізника. Пропонувалось розуміти цей термін чи як товар, що перевозився, чи як судно.

20 Про подібну практику див.: Bravo B. Sulân: représailles et justice privée contre les étrangers dans les cités grecques: étude du vocabulaire et des institutions // Annali della Scuola Normale Superiore di Pisa. Classe di Lettere e Filosofia. 1980. Serie III. Vol. 10. No. 3. P. 675-691, 693-987.

21 Wilson J.-P. Op. cit. P. 37. Вілсон вважає, що Матасій міг вважати Ахіллодора рабом, оскільки у минулому він і справді був рабом Анаксагора, але згодом викупився або був відпущений на волю.
} 
транспортних операціях, можливо, як торгівельні агенти 22.

Нарешті, надзвичайно важливим був той факт, що тепер можна було впевнено відносити початок поширення рабовласницьких відносин в Ольвії практично до часу заснування полісу.

Утім, незважаючи на всю значущість нових даних, новий документ лишався одиничним, адже навіть ті листи, які на той час були знайдені («Лист жерця» або лист Апатурія), десятиліттями чекали на публікацію. Тож немає нічого дивного, що до 1990-х років більшість дослідників або уникала «рабської» проблематики, або доволі скептично оцінювали значення рабовласницьких відносин в ольвійському суспільстві, принаймні, на ранніх етапах ольвійської історії.

Подібний погляд характерний, зокрема, для робіт Н.О. Лейпунської, яка була одним із небагатьох науковців, які плідно займалися вивченням господарства Ольвії. Так, для економіки Ольвії архаїчної доби, на думку Н.О. Лейпунської, характерний «слабкий розвиток рабовласницького господарства як такого»23.

Ще скептичнішу позицію стосовно власне ольвійського рабовласництва зайняла Н.О. Гаврилюк - авторка концепції масштабної скіфської работоргівлі, в якій Ольвії відведено роль одного із головних посередників між степовиками й античними полісами Балкан і Малої Азії - головними споживачами «живого товару». Хоча перше видання її фундаментального дослідження економіки Степової Скіфії вийшло ще у 1999 p. і на момент його написання авторці могла бути невідомою публікація Ю.Г. Виноградова 1998 р., про яку йтиметься далі, але й у другому, істотно доповненому та розширеному виданні, яке побачило світ у 2013 р., дослідниця доволі скептично оцінює масштаби використання рабської праці безпосередньо у господарстві Ольвії ${ }^{24}$.

Можна сказати, що археологи у 1970-1990-ті роки загалом уникали спроб проведення реконструкцій соціальної структури Ольвії на базі численного нового матеріалу як з міста, так і з його сільської округи. Здається, лише В.М. Отрешко свого часу висловлював, нехай і побіжно, думку про масштабне використання рабської праці в ольвійському господарстві 25 .

Окремо слід згадати праці К.К. Марченка, присвячені інтерпретації терміну «ойкети» $з$ декрету на честь Протогена, в яких автор, відповідно до відповідно до своєї концепції «варварської» складової населення Ольвії, воліє бачити радше варварський, аніж грецький його компонент ${ }^{26}$. Утім, варто зазначити, що саме К.К. Марченко прямо поставив, на противагу побудовам В.Д. Блаватського, питання про можливість бачити в ойкетах декрету саме сільськогосподарських рабів. Не останню роль у

22 Матасій твердить, що Ахіллодор - раб, і належить, разом із вантажем та/чи судном, Анаксагорові. Тобто ситуація, коли раб здійснював торгівельно-транспортні операції, не виглядала незвичною для ольвіополітів VI ст. до н.е.

23 Лейпунська Н.О. Становлення античного способу виробництва у Нижньому Побужжі (за археологічними даними) // Археологія. 1991. № 3. С. 86.

24 Гаврилюк Н.А. Экономика Степной Скифии VI-III вв. до н.э. Київ, 2013. С. 479. Щоправда, 3 джерел малої епіграфіки у роботі розглядається лише лист Ахіллодора, хоча на момент публікації вже було відомо п’ять листів, інформація яких безпосередньо стосувалася Ольвії (див. нижче). 25 Отрешко В.М. 3 історії Ольвійського поліса // Археологія. 1982. Вип. 41. С. 38. Згодом ці думки були детальніше розвинуті у колективній монографії, присвяченій ольвійській хорі (Крыжицкий С.Д., Буйских С.Б., Бураков А.В., Отрешко В.М. Сельская округа Ольвии. Київ, 1989. С. 93-94). 26 Марченко К.К. Ойкеты декрета в честь Протогена (IOSPE. I2. 32). К вопросу о зависимом населении Ольвии эллинистического времени // Причерноморье в эпоху эллинизма. Тбилиси, 1985. C. 61-63; Его же. Греки и варвары Северо-Западного Причерноморья скифской эпохи // Греки и варвары Северного Причерноморья в скифскую эпоху. Санкт-Петербург, 2005. С. 129-136. 
цьому зіграли, звісно, масштабні дослідження сільської округи Ольвії, якими було відкрито сотні аграрних поселень ${ }^{27}$, і які не лишали каменя на камені від теоретичних побудов В.Д. Блаватського.

Справжнім проривом у справі поповнення джерельної бази стали 1990-ті роки. У 1993 р. А.С. Русяєвою та Ю.Г. Виноградовим було опубліковано «Лист жерця» 28, у 1998 р. Ю.Г. Виноградов публікує одразу чотири листи на свинцевих пластинках, два з яких безпосередньо стосуються ольвійського рабовласництва29, того ж року Дж.П. Вілсон здійснює попередню публікацію листа Апатурія ${ }^{30}$, яку Виноградов за життя так і не встиг зробити (про повну публікацію див. нижче). Слід підкреслити, що всі чотири епіграфічні документи, як і лист Ахіллодора, містили інформацію про ранній етап розвитку рабовласництва в Ольвї̈, і що ця інформація була надзвичайно різноманітною тематично.

Найдавнішим i, водночас, найгірше збереженим є лист з Березані, датований часом не пізніше третьої чверті VI ст. до н.е. ${ }^{31}$ Згідно з читанням Ю.Г. Виноградова32, у листі згадується дівчина-рабиня, яка передавалась, точніше - поверталась від одного власника іншому. Можливо, йдеться про позику, хоча з тексту листа, сильно фрагментованого, останнє достеменно не зрозуміло.

Чи не найнесподіванішим, з огляду на інформацію, яку він містив, з усіх опублікованих Ю.Г. Виноградовим листів є лист з Фанагорії, датований останньою третиною VI ст. до н.е., в якому йдеться про продаж раба з Борисфенуз3. У листі йдеться про продаж раба з Борисфену. Власне, цей короткий лист містить одразу кілька несподіванок. По-перше, неочікувано раннім виявився початок міжполісної торгівлі рабами - ще з VI ст. до н.е., тобто, по суті, вже під час утвердження греків на північних берегах Понту Евксинського. По-друге, лист свідчить про ранній початок стосунків між греками Нижнього Побужжя та Боспору, які до того ж, майже не фіксуються археологічно. I, нарешті, третьою несподіваною обставиною (напевне, найважливішою 3 огляду на тему цього дослідження) є факт існування місцевого, північнопонтійського ринку рабів, адже є очевидним, що раб з Борисфену вивозився на схід, до Фанагорії аж ніяк не з метою подальшого перепродажу в Грецію. Цікаво також, що раб носить еллінське, а не скіфське чи інше варварське ім'я.

Поряд із листом Ахіллодора, найінформативнішим з-поміж приватних листів (i не лише серед ольвійських) є лист Апатурія з Ольвії, датований часом близько 500 р. до н.е. Цей великий і надзвичайно цікавий лист має доволі драматичну історію публікації. Лист знаходився у розпорядженні Ю.Г. Виноградова, який неодноразово циту-

\footnotetext{
27 Крыжицкий С.Д., Буйских С.Б., Бураков А.В., Отрешко В.М. Сельская округа Ольвии...; Крыжицкий С.Д., Буйских С.Б., Отрешко В.М. Античные поселения Нижнего Побужья (Археологическая карта). Київ, 1990.

28 Русяєва А.С., Віноградов Ю.Г. Лист жерця з Гілеї // Золото степу. Археологія України. КиївШлезвіг, 1991. С. 201-202.

29 Vinogradov Y.G. The Greek Colonisation of the Black Sea Region in the Light of Private Lead Letters // The Greek Colonisation of the Black Sea Area. Historical Interpretation of Archaeology. Stuttgart, 1998. P. 157-178.

30 Wilson J.-P. «The illiterate trader»? // Bulletin of the Institute of Classical Studies. 1997-8. Vol. 42. P. 38ff. 31 Ibid. P. 155-157.

32 Через сильну фрагментованість тексту між дослідниками існували часом суттєві розбіжності в його інтерпретації (див.: Ceccarelli P. Ancient Greek Letter Writing... Р. 336), але більшість дослідників загалом поділяють думку першопублікатора, що в тексті згадується дівчина-рабиня. 33 Vinogradov Y.G. The Greek Colonisation of the Black Sea Region... P. 160-163.
} 
вав його фрагменти у різних працях ${ }^{34}$, але так і не опублікував текст повністю. Після смерті відомого епіграфіста сліди оригіналу губляться, але, на щастя, лишилася промальовка тексту, на підставі якої відомий румунський епіграфіст Мадаліна Дана зробила реконструкцію листа 35 (попередньо, як вже говорилося, лист був опублікований Дж-П. Вілсоном) ${ }^{36}$. Він містить цінну інформацію про торгівельні операції в архаїчній Ольвії, але для дослідника рабства важливішим є той факт, що у тексті згадуються ойкети, тобто домашні (або сільськогосподарські) раби якогось Тимолея. I знов-таки, як і у листі Ахіллодора, йдеться про власника одразу кількох рабів.

Першим за часом публікації, але чи не найпізнішим хронологічно $є$ «Лист жерця» з Гілеї. На відміну від попередніх, він був прокреслений не на свинцевій пластинці, а на кераміці - на стінці амфори чи ойнохої стилю фікеллюра ${ }^{37}$. Документ було знайдено в Ольвії, і датовано приблизно тим самим часом, що й попередній. Текст несе певні складнощі у читанні й інтерпретації38, але для нас найважливішими є два згадані у ньому факти. По-перше, лист засвідчує існування у полісі не лише приватновласницьких рабів, але й рабів, які належали святилищам³9. По-друге, у листі йдеться про втечу рабів після корабельної аварії. Через пошкодження кількох рядків 3 контексту до кінця незрозуміло, ким були ті раби: чи гребцями на судні, чи їх на тому судні перевозили (i, якщо так, то з якою метою). Утім, зважаючи на згадку в тексті про лісозаготівлі, цілком вірогідним виглядає припущення А.С. Русяєвої40, що ці раби могли займатись вирубкою лісу.

Публікація цих листів, а також і тих, які походять 3 території Боспору41, не лише

34 Vinogradov Ju.G. Olbia. Geschichte einer altgriechischen Stadt am Schwarzen Meer. Konstanz, 1981. S. 19, 49. Vinogradov Y.G. The Greek Colonisation of the Black Sea Region... P. 157 та ін.

35 Dana M. Lettre sur plomb d’Apatorios a Léanax. Un document archaïque d'Olbia du Pont// Zeitschrift für Papyrologie und Epigraphik. 2004. 148. P. 1-14.

36 Wilson J.-P. Op. cit.

37 Русяєва А.С., Віноградов Ю.Г. Лист жерця з Гілеї...

38 Див.: Ceccarelli P. Ancient Greek Letter Writing... Р. 339-340.

39 У тексті згадується лише один такий, на ймення Метрофанос, але, зрозуміло, він не був єдиним храмовим рабом на все Нижнє Побужжя.

40 Русяева А.С. Население // Крыжицкий С.Д., Русяева А.С., Крапивина В.В. и др. Ольвия. Античное государство в Северном Причерноморье. Киев, 1999. С. 406.

41 Власне кажучи, лист з Фанагорії теж належить до боспорських, а не до ольвійських. Крім нього, на сьогодні відомі ще чотири листи, які містять відомості про поширення рабовласницьких відносин на Боспорі: 1) лист на свинцевій пластинці з Пантикапея кінця V - початку IV ст. до н.е. (Сапрыкин С.Ю., Федосеев Н.Ф. Фрагмент хозяйственного письма на свинце из Пантикапея // ВДИ. 2010. № 1. С. 50-58), в якому, на думку публікаторів, йдеться про поховання, до якого залучалися раби-копачі; 2) лист на керамічному фрагменті з Горгіппійських наділів, що датується третьою чвертю IV ст. до н.е. (Виноградов Ю.Г. Письмо с горгиппийских наделов // Алексеева Е.М. Античный город Горгиппия. Москва, 1997. C. 544-545; Vinogradov Ju.G. A Letter from Gorgippean Rural Estates // Ancient Civilizations from Scythia to Siberia. 1997. 4.3. P. 232-244), який є безсумнівним свідченням наявності сільськогосподарських рабів в античних державах Надчорномор'я: раб, згаданий у листі з Горгіппійських наділів, безумовно був зайнятий саме у сільському господарстві (судячи з контексту, йдеться про доволі кваліфікованого раба, який мав працювати на винограднику); 3) лист з Патрея (Завойкина Н.В., Павличенко Н.А. Письмо на свинцовой пластине Патрея...), датований його публікаторами останньою чвертю $\mathrm{V}$ ст. до н.е., в якому йдеться про визискування боргів, причому, окрім грошей, один з боржників мав розрахуватись рабами (точніше, одним рабом) і 4) Нещодавно опублікований лист з Мірмекія, датований кінцем IV cт. до н.е. (Бехтер А.П., Бутягин А.М., Дана М. Свинцовое письмо из Мирмекия // Вестник древней истории. 2018. Т. 78. № 4. С. 931-948), в якому, зокрема, йдеться про продаж молодого раба. Отже, на сьогодні загалом відомо щонайменше дев'ять приватних листів з Північного Причорномор'я, що містять різноманітну інформацію про рабовласницькі відносини. 
кількісно, але й якісно збільшила джерельну базу історії античного рабовласництва у Надчорномор'ї загалом і в Ольвії зокрема. Це дало змогу дослідникам розпочати дослідження соціально-економічної структури Ольвійського полісу, активно використовуючи, поряд з археологічними матеріалами та даними «великої» епіграфіки, інформацію з приватних листів. Тут, у першу чергу, слід виокремити написаний А.С. Русяєвою розділ «Населення Ольвії» у колективній монографії «Ольвія: антична держава у Північному Причорномор'ї»42. Характеризуючи соціальну структуру Ольвійського полісу, авторка окремо зупиняється і на його рабській складовій, залучаючи як епіграфічні, так і археологічні матеріали. На відміну від багатьох попередників, А.С. Русяєва не лише вважає, що раби були важливим елементом соціальної структури Ольвії, але й висловлює припущення, що їхня праця використовувалася, перш за все, у сільському господарстві - основі полісної економіки ${ }^{4}$, а також і при заготівлі сировини (вирубці лісу чи обробці каменю), могли вони також працювати різноробами (вантажниками) тощо ${ }^{44}$.

Також авторка висловлює припущення, що значна частина (якщо не більшість) рабів походило з варварського середовища 45 . Очевидно (хоча сама А.С. Русяєва і не артикулює це), що раби-варвари в Ольвії могли з'явитись лише у результаті імпорту «живого товару» від варварських сусідів, і, перш за все, - скіфів-кочовиків. І ця обставина цілком гармонійно вписується в історію работоргівлі у Мілеті та мілетських колоній загалом, адже принаймні ще з VI ст. до н.е. ми маємо дані про наявність в ольвійській метрополії покупних (chattel slaves) рабів-фрігійців, авторства поета VI ст. до н.е. Гіппонакта з Ефесу (fr. 27) ${ }^{46}$. Цілком вірогідно, що торгівля фрігійськими рабами здійснювалась через мілетські колонії Пропонтиди та Чорного моря, підтвердженням чому є почесний декрет з мілетської колонії Кізіку, який датується VI ст. до н.е. (SIG3 4). У ньому, зокрема, йдеться про надання ателії, за винятком кількох податків, серед яких і податок на торгівлю рабами ${ }^{47}$. Другим за важливістю після Малої Азії джерелом поставок рабів на іонійські ринки була Фракія. Вірогідно, що тут основний потік «живого товару» йшов не через чорноморські колонії Мілету, а

\footnotetext{
42 Русяева А.С. Указ. соч. С. 406-407, 416-417, 423-424.

43 Цікаво, що при цьому (Русяева А.С. Указ. соч. С. 420) вона відмовляється бачити в ойкетах декрету на честь Протогена саме сільськогосподарських рабів чи залежних працівників варварського походження (останнє припущення міститься у цитованих вище працях К.К. Марченка). Основним аргументом contra $\epsilon$ твердження, що на момент подій, описаних у Декреті, ольвійська хора переживала повний занепад. Втім, вже після публікації колективної монографії, з'явилися нові дані, згідно з якими окремі поселення ольвійської хори проіснували значно довше, ніж вважалося дотепер. На думку С.Б. Буйських, нині ми маємо говорити не про повну загибель, а радше про редукцію хори Ольвії у другій половині III - середині II ст. до н.е. (Буйских С.Б. Хора колониального полиса в Нижнем Побужье: от архаики к эллинизму // Старожитності Степового Причорномор'я і Криму. 2009. Т. ХV. С. 237).

44 Русяева А.С. Указ. соч. С. 406.

45 Там само.

46 Див. про торгівлю фрігійськими рабами: Lewis D. The Market for Slaves in the Fifth- and FourthCentury Aegean: Achaemenid Anatolia as a Case Study // The Ancient Greek Economy. Markets, Households and City-States. Cambridge, 2016. P. 316-336.

Примітно, що використання цих рабів (які «мелють ячмінь на мілетських млинах») було виразно пов'язаним не з ремеслом, а з сільським господарством: якщо не з виробництвом, то, принаймні, із переробкою аграрної продукції.

47 Аналіз цього декрету у контексті фрігійської работоргівлі див.: Lewis D. The Market for Slaves in the Fifth- and Fourth-Century Aegean... P. 320-321.
} 
через поліси північного узбережжя Егейського моря48. Натомість, мілетські колонії у Добруджі могли слугувати перевалочним пунктом у торгівлі рабами-гетами ${ }^{49}$.

У цьому контексті цілком логічною виглядає роль Ольвії як пункту перепродажу рабів-скіфів (або захоплених скіфами під час набігів). Але масштабність цієї торгівлі і досі викликає доволі суттєві розбіжності - від більш ентузіастичних поглядів (Н.О. Гаврилюк) до куди скептичніших (А.Аврам).

Концепція работоргівлі як основи скіфського експорту з 90-х років минулого століття плідно розробляється відомим скіфологом Н.О. Гаврилюк ${ }^{50}$. Авторка, оцінюючи структуру експорту кочовиків, яким мав компенсуватися імпорт грецьких товарів, особливо предметів престижного вжитку, доводить, що лише торгівля «живим товаром» (а не продуктами тваринництва чи, тим більше, товарним зерном) була здатна забезпечити товарний баланс. Концепція Н.О. Гаврилюк зустріла як підтримку, так і критику. Щоправда, остання стосується не стільки оцінки структури скіфського експорту, скільки доказової бази твердження широкого вивезення рабів-скіфів до Греції: так, Александру Аврам, аналізуючи писемні й епіграфічні джерела понтійської работоргівлі доримського часу, зазначає, що, пишучи про значну кількість вивезених рабів у V ст. до н.е., на підтвердження своїх слів Н.О. Гаврилюк наводить лише одне ім'я раба-скіфа ${ }^{51}$. Втім, варто звернути увагу на специфіку тих епіграфічних джерел, якими користуються дослідники при встановленні етнічного складу рабів, де значну частину становлять мануміссії52. У цьому випадку, звичайно, йтиметься головним чином про кваліфікованих рабів 53 , тоді як скіфи, без сумніву, у своїй абсолютній більшості до таких не належали.

Натомість, інформація згаданого вище листа VI ст. до н.е. на свинцевій пластині 3 Фанагорії, опублікованого Ю.Г.Виноградовим, дає змогу поставити питання про внутрішньопонтійський ринок «живого товару». А це, разом із усією наявною на сьогодні інформацією, дозволяє ставити питання про сфери використання рабської праці, адже у більшості понтійських полісів, зокрема і в Ольвї̈, не було ані розвинутої гірничої справи, подібної до експлуатації копалень Лавріону в Аттиці, ані високотоварного ремісничого виробництва 54 . Тому говорити про значну питому вагу праці

\footnotetext{
48 Свідченням цього є, зокрема, фрагментований декрет з теоської колонії Абдери $(\operatorname{SEG} 47,1026)$, який, щоправда, датується значно пізнішим часом, аніж кізікський - IV ст. до н.е., який регламентує продаж рабів і в'ючних тварин (примітним $\epsilon$ те, що й тут худоба і невільники також згадуються в одному контексті). Див.: Archibald Z. Ancient Economies of the Northern Aegean: Fifth to First Centuries BC. Oxford, 2014. P. 120-122.

49 Так, Дж. Гінд припускає, що на монетах Iстрії середини V - першої чверті IV ст. до н.е. зображені саме гетські раби (Hind J. The trade in Getic Slaves and the Silver Coins of Istria // Thracia Pontica. 1994. Vol. 5. P. 153-158). Утім, ця гіпотеза є дискусійною.

50 Гаврилюк Н.А. История экономики Степной Скифии VI-III вв. до н.э. Киев, 1999. С. 277; Gavriljuk N.A. The Graeco-Scythian slave-trade in the 6th and 5th centuries BC // P.G. Bilde, J.M. Højte and V.F. Stolba (Eds.). The Cauldron of Ariantas. Studies presented to A.N. Sčeglov on the occasion of his 70th birthday. Aarhus, 2003. P.75-85. Див. також друге, доповнене видання монографії: Гаврилюк Н.А. Экономика Степной Скифии VI-III вв. до н.э. Киев, 2013. С. 452-486.

51 Avram A. Some Thoughts about the Black Sea and the Slave Trade before the Roman Domination (6th - 1st Centuries BC) // V. Gabrielsen and J. Lund (Eds.) The Black Sea in Antiquity. Regional and Interregional Economic Exchanges, (Black Sea Studies, 6). Aarhus, 2007. P. 242, 248 note 21.

52 Див. напр.: Lewis D. Near Eastern slaves in Classical Attica and the slave trade with Persian territories // The Classical Quarterly. 2011. Vol. 61. № 1. P. 96 ff.

53 Див. напр: Westermann W.L. The Slave Systems of Greek and Roman Antiquity. Philadelphia, 1955. P.13 ff.

54 Тут знов-таки зазвичай згадуються Афіни, де в ергастеріях, подібних до зброярської та меблевої майстерень Демосфена-батька (Dem., XXVII, 9; 18), працювали десятки рабів.
} 
рабів у місцевому господарстві можна лише у випадку їх широкого залучення до аграрного виробництва, адже саме сільське господарство практично одностайно визнається провідною галуззю економіки античних держав Північної Надчорноморщини взагалі, й Ольвії зокрема.

Аналіз наявної джерельної бази, разом із залученням порівняльно-історичної інформації, дозволяє стверджувати про можливість доволі значного поширення практики використання рабської праці у сільському господарстві Ольвї, принаймні, у господарстві заможних землевласників 55 . І хоча раби, згадувані у листах Ахіллодора й Апатурія, могли належати як до сільських, так і до міських ойкосів 56 , ойкети декрету на честь Протогена, судячи з контексту (IOSPE I2, 32B, 5-21) напевно були пов'язані саме із господарствами хори. Навряд чи буде надто сміливим уважати, що майже всі раби в ойкосах ольвійської периферії були так чи інакше пов'язані із сільським господарством, як не 3 виробництвом відповідної продукції, то 3 її переробкою. Типовим прикладом останнього є прядіння та ткацтво - традиційне заняття домашніх рабинь у Греції. Враховуючи сприятливі умови для розвитку продуктивного вівчарства у Нижньому Побужжі, наявність тут значного числа рабинь-ткаль виглядає цілком вірогідною.

Говорячи про розвиток еллінами аграрного виробництва у Степовому Надчорномор'ї, слід звернутися до гіпотези Віктора Генсона, згідно з якою технологічні інновації, включно із широким залученням праці покупних рабів до праці в аграрній сфері, пов'язані перш за все з маргінальними землями (eschate), успішне освоєння яких було можливим лише за рахунок нових, якісніших за ті, що практикувалися на рівнинах, аграрних технологій 57 , а також інтенсивнішого використання робочої та, перш за все, - рабської сили ${ }^{58}$. У Середземномор'ї це були, головним чином, гірські землі, які потребували терасування ${ }^{59}$. Можна цілком обгрунтовано припускати, що для греків, принаймні на початку колонізації, степові ландшафти також були маргінальними по відношенню до тих, до яких вони звикли у метрополії, а процес підняття степової цілини, як і терасування схилів, є трудомістким і потребує залучення значних трудових ресурсів ${ }^{60}$. Виходячи $з$ цього, використання рабської праці було

55 Одрін О. Рабська праця у сільському господарстві Ольвійського поліса: до постановки проблеми // Український історичний журнал. 2018. № 3. С. 4-22.

56 В останньому випадку вони названі терміном «ойкети», що часто (але далеко не завжди) означав саме рабів, задіяних у сільському господарстві.

57 Це підтверджується й даними епіграфіки: Jameson M.H. Class in the ancient Greek countryside // Doukellis P.N. and Mendoni L.G. (Eds.) Structures Rurales Et Sociétés Antiques: Actes Du Colloque de Corfou, 14-16 Mai 1992. Paris, 1994. P. 57.

58 Так, саме на гірських терасах Хіосу, як вважали античні автори, вперше в античному світі почали широко використовувати працю покупних рабів. Див.: Шишова И.А. Рабство на Хиосе // Рабство на периферии античного мира. Ленинград, 1968. С. 49-92.

${ }^{59}$ Hanson V.D. The Other Greeks The Family Farm and the Agrarian Roots of Western Civilization. Berkeley-Los Angelos-London, 1999. P. 79-88. Див. також: Jameson M.H. Attic Eschatia // Ancient History Matters: studies presented to Jens Erik Skydsgaard. Rome, 2002. P. 63-68.

60 Взагалі, проблема колоній як провідників технічних інновацій в аграрній сфері є складною та потребує грунтовного дослідження, особливо зважаючи на приток нової інформації, зокрема археологічної й археобіологічної (див., наприклад, дослідження аграрної історії полісів Південної Італії та Сицилії: Carter J.C. Discovering the Greek Countryside at Metaponto. Ann Arbor, 2006; De Angelis F. Archaic and classical Greek Sicily: a social and economic history. Oxford, 2016 та ін.).

Про складнощі в освоєнні греками степових земель див.: Одрін О.В. Адаптація технології землеробства грецьких колоністів до екологічних умов Північного Причорномор'я наприкінці VII - VI ст. до н.е.: постановка проблеми // Україна крізь віки: Збірник наукових праць на пошану академіка НАН України професора Валерія Смолія. Київ, 2010. С. 99-114. 
очевидним виходом для ольвійських землеробів, особливо зважаючи на можливість постійно поповнювати «рабські ресурси» торгівлею зі степовиками 61.

Про інші можливі сфери використання рабської праці в Ольвії вже говорилося вище. До них слід віднести видобуток сировини (лісу і, можливо, будівельного каменю) та торгівельно-транспортні операції, де раби могли виступати й у ролі торгівельних агентів.

Тепер варто, бодай коротко, зупинитись на операціях з «живим товаром», про які згадується у джерелах. Поряд із продажем рабів, про який вже говорилося, існувала і практика передачі рабів у тимчасову власність, про що йдеться у згаданому вище листі з Березані, датованому близько 540-535 рр. до н.е. 3 території Ольвії поки що невідомі листи, де мовилось би про використання рабів у якості закла́ду, але, зважаючи на існування подібних практик на Боспорі62, можна припускати побутування такої практики і в Ольвії. Таким чином, ми можемо твердити, що в Ольвійському полісі (практично від часу його заснування) «живий товар» був предметом різноманітних операцій (продаж, позика, заклад). При цьому продаж відбувався як на внутрішньому, так і на зовнішньому ринках.

Отже, попри всю неповноту джерельної бази 63 , вже зараз можна впевнено стверджувати, що рабовласницькі відносини ще з другої половини VI ст. до н.е. були поширеними у різних сферах життя Ольвійського полісу. Тож, якщо раніше дослідники у своїх працях часто були змушені обмежуватись загальними теоретичними міркуваннями, то нині гіпотези вже можуть будуватись на фактичній базі, попри природну неповноту останньої. Оцінка масштабів використання рабської праці у різних галузях його господарства - предмет подальших спеціальних міждисциплінарних досліджень, в яких має бути синтезовано дані епіграфіки й археології, які наразі до вивчення розглянутої теми залучалися доволі спорадично.

Особливо слід наголосити на необхідності якомога ширше залучати для порівняльного аналізу матеріали з інших регіонів давньогрецького світу (не лише з Аттики): епіграфічні, археологічні й археобіологічні, етноархеологічні дані. Необхідно також якомога ширше використовувати напрацювання світової історіографії з різних питань соціально-економічної історії Давньої Греції (і перш за все, звичайно - 3 питань рабовласництва), тим більше, що в останні десятиліття тут відбулися суттєві зрушення: побачило світ чимало новаторських праць, деякі з яких були згадані вище. Подальші наукові студії мають бути спрямованими, зокрема, і на детальний аналіз соціальної та майнової структури ольвійської громади, на співвідношення ролі економічної верхівки (аристократів та/чи тимократів) і людей середнього достатку в різних сферах виробництва, а також на питаннях забезпеченості виробництва робочою силою, зокрема рабською. Всі ці фактори відкривають нові перспективи у дослідженні соціально-економічної історії Ольвії, зокрема історії рабовласництва у цьому полісі.

\section{REFERENCES}

Archibald, Z. (2014). Ancient Economies of the Northern Aegean: Fifth to First Centuries BC. Oxford [in English].

\footnotetext{
61 Гаврилюк Н.А. Экономика Степной Скифии... С. 452-486.

62 Про це свідчить згаданий вище лист з Патрея.

63 Можна сподіватись і на суттєве поповнення бази «малої» епіграфіки, принаймні за рахунок обробки неопублікованих листів з фондів наукових інститутів і з приватних колекцій. Принаймні, в останні роки подібні пам'ятки вводяться до наукового обігу достатньо регулярно.
} 
Avram, A. (2007). Some Thoughts about the Black Sea and the Slave Trade before the Roman Domination (6 $6^{\text {th }}-1^{\text {st }}$ Centuries BC). In V. Gabrielsen \& J. Lund (Eds.). The Black Sea in Antiquity. Regional and Interregional Economic Exchanges (pp. 239-251). Aarhus: Aarhus University Press [in English].

Behter, A.P., Butiagin, A.M. \& Dana, M. (2018). Svintsovoe pismo iz Mirmekiia [Lead Letter from Myrmekion]. Vestnik drevnei istorii, 78, 4, 931-948. doi: 10.31857/S032103910002911-5 [in Russian].

Blavatskii, V.D. (1953). Zemledelie v antichnykh gosudarstvakh Severnogo Prichernomoria [Agriculture in Antique States in Northern Black Sea Area]. Moscow [in Russian].

Blavatskii, V.D. (1954). Rabstvo i ego istochniki v antichnykh gosudarstvakh Severnogo Prichernomoria [Slavery and its sources in Antique States in Northern Black Sea Area]. Sovetskaia Arkheologia, XX, 31-56 [in Russian].

Bravo, B. (1980). Sulân: représailles et justice privée contre les étrangers dans les cités grecques: étude du vocabulaire et des institutions. Annali della Scuola Normale Superiore di Pisa. Classe di Lettere e Filosofia, III.10. 3, 675-691, 693-987 [in French].

Buiskikh, S.B. (2009). Khora kolonialnogo polisa v Nizhnem Pobuzhe: ot arkhaiki k ellinizmu [Chora of Colonial Polis in the Lower Bug River Region: from the Archaic to the Hellinism]. Starozhytnosti Stepovoho Prychornomoria i Krymu, XV, 227-243 [in Russian].

Carter, J.C. (2006). Discovering the Greek Countryside at Metaponto. Ann Arbor [in English].

Ceccarelli, P. (2013). Ancient Greek Letter Writing: A Cultural History (600 BC - 150 BC). Oxford [in English].

Dana, M. (2004). Lettre sur plomb d’Apatorios a Léanax. Un document archaïque d'Olbia du Pont. Zeitschrift für Papyrologie und Epigraphik, 148, 1-14 [in French].

De Angelis, F. (2016). Archaic and classical Greek Sicily: a social and economic history. Oxford [in English].

Finley, M. (1980). Ancient Slavery and Modern Ideology. New York [in English].

Gavriliuk, N.A. (1999). Istoriia ekonomiki Stepnoi Skifii VI-III vv. do n.e. [History of Economics of Steppian Scythians in VI-III BC]. Kyiv [in Russian].

Gavriljuk, N.A. (2003). The Graeco-Scythian Slave-trade in the $6^{\text {th }}$ and $5^{\text {th }}$ centuries BC. In P.G. Bilde, J.M. Højte \& V.F. Stolba (Eds.). The Cauldron of Ariantas. Studies presented to A.N. Sčeglov on the Occasion of His 70th Birthday (pp. 75-85). Aarhus: Aarhus University Press [in English].

Gavriliuk, N.A. (2013). Ekonomika Stepnoi Skifii VI-III vv. do n.e. [Economy of Steppe Scythia in VI-III centuries BC]. Kyiv [in Russian].

Hanson, V.D. (1999). The Other Greeks. The Family Farm and the Agrarian Roots of Western Civilization. Berkeley-Los Angelos-London [in English].

Hind, J. (1994). The trade in Getic Slaves and the Silver Coins of Istria. Thracia Pontica, 5, 153-158 [in English].

Jameson, M.H. (1994). Class in the ancient Greek countryside. In Doukellis, P.N. \& Mendoni, L.G. (Eds.). Structures Rurales Et Sociétés Antiques: Actes Du Colloque de Corfou, 14-16 Mai 1992 (pp. 55-63). Presses Univ. Franche-Comté [in English].

Jameson, M.H. (2002). Attic Eschatia. In Ancient history matters: studies presented to Jens Erik Skydsgaard on His 70th Birthday (pp. 63-68). L'Erma di Bretschneider [in English].

Kallistov, D.P. (1968). Rabstvo v Severnom Prichernomore V-III vv. do n.e. [Slavery in Northern Black Sea Area]. In Rabstvo na periferii antichnogo mira (pp. 193-221). Leningrad: Nauka [in Russian].

Kotsevalov, A. (1955). Antichnaia istoriia i kultura Severnogo Prichernomoria v sovetskom nauchnom issledovanii [Antique history and culture in Soviet scientific research]. Münich. [in Russian].

Kotsevalov, A. (1956). Antichnoe rabstvo v sovetskoi literature [Antique Slavery in Soviet literature]. Münich. [in Russian].

Kryzhickii, S.D., Buiskikh, S.B., Burakov, A.V. \& Otreshko, V.M. (1989). Selskaia okruga Olvii [Rural countryside of Olbia]. Kyiv: Naukova Dumka [in Russian].

Kryzhickii, S.D., Buiskikh, S.B. \& Otreshko, V.M. (1990). Antichnye poseleniia Nizhnego Pobuzhia (arkheologicheskaia karta) [Antique Settlements in Lower Bug Region (Archaeological Map)]. Kyiv [in Russian].

Leipunska, N.O. (1991). Stanovlennia antychnoho sposobu vyrobnytstva u Nyzhniomu Pobuzhzhi (za arkheolohichnymy danymy) [Formation of the Antique Method of Production in the Lower Bug Area (by the archeological data)]. Arkheolohiia, 3, 76-86 [in Ukrainian].

Lentsman, Ya.A. (1963). Rabstvo v mikenskoi i gomerovskoi Gretsii [Slavery in Mycenaean and Homeric Greece]. Moscow [in Russian].

Lewis, D. (2011). Near Eastern slaves in Classical Attica and the slave trade with Persian territories. The Classical Quarterly, 61, 1, 91-113. doi: 10.1017/S0009838810000480 [in English]. 
Lewis, D. (2016). The Market for Slaves in the Fifth- and Fourth-Century Aegean: Achaemenid Anatolia as a Case Study. In Woolmer, M., Lewis, D., Harris, E.M. (Eds.) The Ancient Greek Economy. Markets, Households and City-States (pp. 316-336). Cambridge University Press [in English].

Lewis, D. (2018). Greek Slave Systems in their Eastern Mediterranean Context, c. 800-146 BC. Oxford [in English].

Marchenko, K.K. (1985). Oikety dekreta v chest Protogena (IPE, I2,32). K voprosu o zavisimosti naseleniia Olvii ellinisticheskogo vremeni [Oiketes of Protogen's Decree (IPE, I2 32 ). To the Question of Dependence of Olbian Population in Hellenistic time]. Prichernomore v epohu ellinizma, 242-256 [in Russian].

Marchenko, K.K. (2005). Greki i varvary Severo-Zapadnogo Prichernomoria skifskoi epokhi [Greeks and Barbarians in North-Western Black Sea Region in Scythian era]. In Marchenko, K.K. (Ed.). Greki $i$ varvary Severnogo Prichernomoria v skifskuiu epokhu (pp.129-136). Sankt-Peterburg: Aleteia [in Russian].

Odrin, O.V. (2010). Adaptatsiia tekhnolohii zemlerobstva hretskykh kolonistiv do ekolohichnykh umov Pivnichnoho Prychornomoria naprykintsi VII - VI st. do n.e.: postanovka problemy [Adaptation of agricultural technology of the Greek colonists to the ecological conditions of the Northern Black Sea Region (the end of the VII-VI centuries BC): Statement of the problem]. In: Ukraina kriz viky: Zbirnyk naukovykh prats na poshanu akademika NAN Ukrainy profesora Valeriia Smoliia (pp. 99-114). Kyiv: Instytut istorii Ukrainy NAN Ukrainy [in Ukrainian].

Odrin, 0. (2018). Rabska pratsia u silskomu hospodarstvi Olviiskoho polisa: do postanovky problemy [Slave Labor in the Agriculture of the Olbia Police: to the Problem]. Ukrainskyi istorychnyi zhurnal, 3, 4-22 [in Ukrainian].

Otreshko, V.M. (1982). Z istorii Olviiskoho polisa [From the history of the Olbia Polis]. Arkheolohiia, 41, 34-46 [in Ukrainian].

Rusiaieva, A.S. \& Vinogradov, Yu.G. (1991). Lyst zhertsia z Hilei [Letter of the Priest from Hylaie]. In Tolochko, P.P. \& Murzin, V.Y. (Eds.) Zoloto stepu. Arkheolohiia Ukrainy (pp. 201-202). Kyiv-Shlezvih [in Ukrainian].

Rusiaeva, A.S. (1999). Naselenie Olvii [Population of Olbia]. In Kryzhickii, S.D., Rusiaeva, A.S., Krapivina, V.V., Skrzhinskaia, M.V. \& Anokhin, V.A. Olviia. Antichnoe gosudarstvo $v$ Severnom Prichernomore (pp. 391-471). Kiev: Institut arkheologii NAN Ukrainy [in Russian].

Saprykin, S.Yu. \& Fedoseev, N.F. (2010). Fragment khoziaistvennogo pisma na svince iz Pantikapeia [A Fragment of Economic letter on lead from Panticapaeum]. Vestnik drevnei istorii, 1, 50-58 [in Russian].

Shishova, I.A. (1968). Rabstvo na Khiose [Slavery on Chios]. In Kallistov D.P. (Ed.) Rabstvo na periferii antichnogo mira (pp. 149-192). Leningrad: Nauka [in Russian].

Vinogradov, Yu.G. (1971). Drevneishee grecheskoe pismo s ostrova Berezan [The Earliest Greek Letter from Berezan Island]. Vestnik drevnei istorii, 4, 74-100 [in Russian].

Vinogradov, Ju.G. (1981). Olbia. Geschichte einer altgriechischen Stadt am Schwarzen Meer. Konstanz [in German].

Vinogradov, Yu.G. (1989). Politicheskaia istoriia Olviiskogo polisa [Political history of the Olbia Polis]. Moscow [in Russian].

Vinogradov, Yu.G. (1997). Pismo s gorgippiiskikh nadelov [A Letter from Gorgippean Rural Estates]. In Alekseeva E.M. Antichnyi gorod Gorgippiia (pp. 544-545). Moskva [in Russian].

Vinogradov, Ju.G. (1997). A Letter from Gorgippean Rural Estates. Ancient Civilizations from Scythia to Siberia, 4.3, 232-244 [in English].

Vinogradov, Ju.G. (1998). The Greek Colonisation of the Black Sea Region in the Light of Private Lead Letters. In Gocha R. Tsetskhladze, Vanessa B. Gorman (Eds.) The Greek Colonisation of the Black Sea Area. Historical Interpretation of Archaeology (pp. 153-178). Franz Steiner Verlag [in English].

Vlassopoulos, K. (2016). Finley's Slavery. Jew, D., Osborne, R. and Scott, M. (Eds.) M.I. Finley: An Ancient Historian and his Impact. 76-99 [in English].

Westermann, W.L. (1955). The Slave Systems of Greek and Roman Antiquity. Philadelphia [in English].

Wilson, J.-P. (1997-98). The «illiterate trader»? Bulletin of the Institute of Classical Studies, 42, 29-56 [in English].

Zavoikina, N.V., Pavlichenko, N.A. (2016). Pismo na svintsovoi plastine iz Patreia [The letter on the lead plate from Patraaeum]. In: V.D. Kuznetsov, A.A. Zavoikin (Eds.) Fanagoriia. Rezultaty arheologicheskih issledovanii, T. 4 (pp. 230-249). Moskva [in Russian].

Zhebelev, S.A. (1938). Poslednii Perisad i skifskoe vosstanie na Bospore. Vestnik drevnei istorii, 3, 43-71 [in Russian]. 


\section{Oleksandr Odrin}

(Institute of History of Ukraine NAS of Ukraine, Kyiv, Ukraine)

ORCID: https://orcid.org/0000-0002-2729-6548

\section{Slavery in Olbia Polis in the $5^{\text {th }}-3^{\text {rd }}$ Centuries BC: Historiography, Sources, Prospects of Research}

The paper is devoted to the analysis of the source base and historiography of the study of slave relations in Pontic Olbia. The limited source base hampered the study of slavery in Olbia polis for a long time. At times, that led to forming hypotheses based on ideological, not backed by factual data, clichés, and sometimes made the researchers completely avoid issues considering Olbia social history.

In recent decades, new sources have been introduced into the scientific circulation, the most informative of which are private letters on lead plates and ceramics, the information on which enables significant intensification of the study of Olbia social history, including slave relations.

New sources have made it possible to confidently, and not hypothetically, date the spread of slavery in various spheres of the social and economic life of Olbia to the initial stages of the polis formation (the earliest known letter dated the third quarter of the $6^{\text {th }}$ century BC). Just in the last third of that century, Olbia slaves also appeared on foreign markets.

Thanks to both new facts and comparative historical information, the practice of using slave labor in Olbia's agriculture can be reasonably assumed, at least, on the land plots of wealthy landowners. Participation of slaves and freedmen in trade operations is an ascertained fact. Slave labor was also quite probably used in logging.

It can also be said about various «living goods» operations, such as mortgages, loans, and sales, with slaves supplied both to home and foreign markets.

Besides analyzing the information of epigraphic and written sources, the paper outlines the directions of further research, which should be based on a comprehensive study of epigraphic and archaeological sources, taking into account theoretical achievements of contemporary historiography. This should allow trying to estimate the scale of the slave labor used in various sectors of Olbia economy and, possibly, estimating the proportion of slaves in the social structure of the polis.

Keywords: Olbia, slavery, slave trade, historiography, Northern Black Sea region 